\title{
Association between serum 25(OH)D and death from prostate
}

\section{cancer}

\author{
S Tretli', ${ }^{1,2}$ E Hernes ${ }^{1,3}$, JP Berg ${ }^{4,5}$, UE Hestvik' and TE Robsahm*,1 \\ 'The Cancer Registry of Norway, Institute of Population-based Cancer Research, Oslo, Norway; ${ }^{2}$ Department of Community Medicine and General \\ Practice, NTNU, Trondheim, Norway; ${ }^{3}$ The Norwegian Radium Hospital, Montebello, Norway; ${ }^{4}$ Hormone Laboratory, Aker University Hospital, Oslo, \\ Nonway; ${ }^{5}$ Faculty Division Ullevål University Hospital, University of Oslo, Oslo, Norway
}

Based on observations that for certain cancers, mortality varies according to sun exposure, vitamin $D$ has been proposed to influence on disease progression. This study aims to investigate whether serum levels of $25(\mathrm{OH}) \mathrm{D}$ are associated with prognosis in patients with prostate cancer. In total, 160 patients with a serum sample in the JANUS serum bank were included. For I 23 patients a pretreatment serum sample was taken, whereas 37 of the patients had received hormone therapy prior to the blood collection. The serum level of $25(\mathrm{OH}) \mathrm{D}$ was classified as low $\left(<50 \mathrm{nmoll} \mathrm{I}^{-1}\right)$, medium $\left(50-80 \mathrm{nmol} \mathrm{I}^{-1}\right)$ or high $\left(>80 \mathrm{nmoll}{ }^{-1}\right)$. A Cox proportional hazard regression model was used to assess the association between serum $25(\mathrm{OH}) \mathrm{D}$ and cancer mortality. During follow-up, 61 deaths occurred, of whom 52 died of prostate cancer. The median time of follow-up was 44.0 months (range, I.2154.6). Serum 25(OH)D at medium or high levels were significantly related to better prognosis (RR 0.33; 95\% Cl 0.14-0.77, RR 0.1 6; 95\% Cl 0.05-0.43) compared with the low level. Analysis restricted to patients receiving hormone therapy gave a stronger association. The serum level of $25(\mathrm{OH}) \mathrm{D}$ may be involved in disease progression and is a potential marker of prognosis in patients with prostate cancer.

British Journal of Cancer (2009) I 00, 450-454. doi:I0.1038/sj.bjc.6604865 www.bjcancer.com

Published online 20 January 2009

(c) 2009 Cancer Research UK

Keywords: 25(OH)D; serum; prostate cancer; prognosis; mortality

The prehormone vitamin $\mathrm{D}$ is well known for its important role in calcium regulation and mineralisation of the bone. However, during the last two decades accumulating evidence suggests that vitamin $\mathrm{D}$ also influences several other biological processes. As early as 1941, an inverse association between ultraviolet radiation and cancer mortality was suggested (Apperly, 1941). By 1980, the hypothesis that vitamin $\mathrm{D}$ deficiency resulting from insufficient sun exposure increased mortality from colon cancer was proposed (Garland and Garland, 1980). The mortality rates for cancer of the breast, prostate, lung, skin and lymphoma have subsequently been shown to vary according to variation in sun exposure (John et al, 1999; Freedman et al, 2002; Grant, 2002; Robsahm et al, 2004; Berwick et al, 2005; Porojnicu et al, 2005, 2007). Results from recent studies indicate that vitamin $\mathrm{D}$ also might influence cancer incidence (see Giovannucci, 2005) through mechanisms that influence cancer development and progression and less likely as a part of the cancer initiation. Vitamin D deficiency is suggested to be a risk factor for prostate cancer (Schwartz and Hulka, 1990; Luscombe et al, 2001). The effect of vitamin $\mathrm{D}$ on cancer processes has repeatedly been demonstrated in experimental studies (see Holick, 2006) as it regulates cell cycle processes such as proliferation, apoptosis and angiogenesis in different tissues.

\footnotetext{
*Correspondence: Dr TE Robsahm, The Cancer Registry of Norway, Institute of Population-based Cancer Research, PB 5313, Majorstua, Oslo 0304, Norway; E-mail: trude.eid.robsahm@kreftregisteret.no

Received 23 September 2008; revised 2 December 2008; accepted 5 December 2008; published online 20 January 2009
}

Although several factors influence the level of circulating vitamin $\mathrm{D}$, skin exposure to sunlight is the most important factor. The main dietary contributors include fatty fish, cod liver oil, eggs, and vitamin $\mathrm{D}$ fortified dairy products. The biologically most active form of vitamin $\mathrm{D}$, calcitriol $\left(1,25(\mathrm{OH})_{2} \mathrm{D}\right)$, is formed from calcidiol $(25(\mathrm{OH}) \mathrm{D})$ in the kidney and is kept at a virtually constant level in serum by parathyroid hormone. However, local production of $1,25(\mathrm{OH})_{2} \mathrm{D}$ occurs in different tissues including prostate cells (Schwartz et al, 1998), where it regulates key processes as cell differentiation and proliferation (Hansen et al, 2001; Omdahl et al, 2002). 1,25(OH $)_{2} \mathrm{D}$ acts by binding to nuclear vitamin $\mathrm{D}$ receptors (VDR), and regulates gene transcription. The amount of vitamin $\mathrm{D}$ available in the body is closely associated to the concentration of the vitamin $\mathrm{D}$ metabolite, $25(\mathrm{OH}) \mathrm{D}$, in the blood. Thus, measurement of circulating $25(\mathrm{OH}) \mathrm{D}$ is the best method to estimate vitamin D availability in the body (Freedman et al, 2007).

During the winter months at northern latitudes, there is an insufficient amount of UVB in the sunlight to generate vitamin D production in the skin. In Norway, the daily maximum UV-indices vary from zero during the winter months (November-February) to 4.5-6.5 (possible range 0-10) in the mid-summer (Johnsen et al, 2002). Similarly, the level of $25(\mathrm{OH}) \mathrm{D}$ vary throughout the year, with a mean in the Norwegian population of about $50 \mathrm{nmoll}^{-1}$ during the winter to about $70-80 \mathrm{nmoll}^{-1}$ during the summer (Moan and Porojnicu, 2006). By using season of diagnosis as an indicator for the level of vitamin $\mathrm{D}$, we previously have investigated a possible relationship between vitamin $\mathrm{D}$ and cancerspecific survival. Patients who were diagnosed with cancer of the breast, colon, prostate, lung or lymphoma during summer or 
autumn were found to have better prognosis (15-50\%) than patients diagnosed during the winter months (Robsahm et al, 2004; Porojnicu et al, 2005, 2007). Similar results were observed in a recent study from the UK, which included more than one million cancer patients (Lim et al, 2006). A main weakness in these studies is the ecological study design, only using season of diagnosis as a proxy of vitamin $\mathrm{D}$.

This study investigates the relationship between vitamin $\mathrm{D}$ and prognosis in patients with prostate cancer, using individual serum levels of $25(\mathrm{OH}) \mathrm{D}$. The results are discussed in terms of the hypothesis that vitamin D suppress cancer processes.

\section{MATERIALS AND METHODS}

The JANUS serum bank was established in 1973, and has serum samples from more than 330000 healthy donors. Donors who developed cancer and were admitted to the Norwegian Radium Hospital (NRH) for treatment, were asked to donate an additional serum sample to JANUS. The NRH has national responsibilities for specialist medicine, including oncology.

This study is based on 160 patients with histologically verified prostate cancer, diagnosed during the period 1984-2004, who donated serum samples to JANUS. When admitted to the NRH for treatment of their prostate cancer these patients donated a second serum sample to JANUS, which was the inclusion criterion of this study. The serum samples were collected within 30 days of hospitalisation at the $\mathrm{NRH}$, and all patients were alive at least 30 days after the date of serum collection. We had no access to the blood sample taken prior to the cancer disease. A linkage between the Cancer Registry of Norway and JANUS was made through the unique personal identification number (PIN) that identifies each Norwegian citizen. Through this PIN patients were linked to the National Death Registry, which provided information on the date and cause of death up to and including 31 December 2005.

Seventy-five microlitres of serum was drawn from each patient's sample for the 25(OH)D analyses. The level of circulating $25(\mathrm{OH}) \mathrm{D}$ was measured using a competitive radioimmunoassay (RIA) (DiaSorin, Stillwater, MN, USA). The RIA is a combined measure of 25-hydroxyvitamin $\mathrm{D}_{3}$, and 25-hydroxyvitamin $\mathrm{D}_{2}$, which have similar biological activities. The total analytical coefficient of variation was between $13-16 \%$ for low, medium and high levels of $25(\mathrm{OH}) \mathrm{D}$. Before any further statistical analyses were performed, the patient's serum level of $25(\mathrm{OH}) \mathrm{D}$ was categorised as follows: low (below $50 \mathrm{nmoll}^{-1}$ ), medium $\left(50-80 \mathrm{nmoll}^{-1}\right)$, and high (above $80 \mathrm{nmoll}^{-1}$ ). Clinical information about tumour differentiation grade (WHO criteria) (Mostofi, 1980) and functional status at time of hospitalisation at the $\mathrm{NRH}$, as well as treatment information, was retrieved from the medical records (NRH). Functional status was defined as good if performance status, defined by Eastern Cooperative Oncology Group (Oken et al, 1982), was $\leqslant 2$ and less good if the status was 3 or 4 . Patient information from the medical records was collected without the knowledge of the individual 25(OH)D level.

The patients were split into two groups. Patient group I consists of 37 patients, who were diagnosed with prostate cancer at another hospital before the blood donation to JANUS at the NRH. All these patients were on hormonal treatment when entering the NRH. The average time between diagnosis and time of $25(\mathrm{OH}) \mathrm{D}$ measurement was 2.4 years. The 123 patients included in patient group II donated the serum sample to JANUS at the time of diagnosis, prior to any treatment. After blood sampling all these patients received treatment: radio therapy $(n=20)$, surgery $(n=29)$, unspecified treatment $(n=14)$ or hormones $(n=60)$. Altogether, 97 of the 160 patients received hormone therapy. The hormone therapy given was luteinising hormone-releasing hormone $(n=54)$, orchiectomi $(n=26)$, anti-androgen $(n=9)$ or other hormones $(n=8)$. Four patients received both radiation and hormone therapy.
The patients were followed from the date of $25(\mathrm{OH}) \mathrm{D}$ measurement until date of death, migration or to the end of follow-up (31 December 2005), whichever occurred first. Cox proportional hazard regression models (SPSS for Windows, Version 15.0, 2007) was used to assess the relationship between serum 25(OH)D level and risk of death from prostate cancer (cause-specific mortality) and death from all causes (mortality).

\section{RESULTS}

\section{Cause-specific mortality}

During the time of follow-up, 61 patients died, of whom 52 died from prostate cancer. The median time of follow-up was 44.0 months (range, 1.2-154.6). Patient characteristics (age, tumour differentiation grade, functional status, serum level of PSA) and $25(\mathrm{OH}) \mathrm{D}$ measured at the time of hospitalisation at the $\mathrm{NRH}$ are presented for all patients, and for patient group I and II separately in Table 1.

The upper part of Table 2 shows the relationship between $25(\mathrm{OH}) \mathrm{D}$ levels and the risk of death from prostate cancer (group I + II). The hazard ratios for patients with medium and high levels of serum $25(\mathrm{OH}) \mathrm{D}$ were 0.48 (95\% CI: $0.24-0.97)$ and $0.34(95 \%$ CI: $0.15-0.77)$ respectively, compared with the patients with low serum levels (Model I). For Model II, when patient group and age were included in the model, patient group status was significant, but did not influence the estimated effect of 25(OH)D. On adding tumour differentiation grade and the patient functional status at the time of blood collection (Model III) a stronger association between $25(\mathrm{OH}) \mathrm{D}$ level and the risk of death from prostate cancer was observed.

During the time of follow-up, 33 deaths occurred in patient group I, all due to prostate cancer. The relative risks of dying were 0.31 (95\% CI: $0.13-0.73$ ) and 0.26 (95\% CI: $0.10-0.68)$ for patients with medium or high serum levels of $25(\mathrm{OH}) \mathrm{D}$, respectively, compared to patients with low 25(OH)D levels (Table 2, Group I). The results were not substantially altered when age at diagnosis was included (Model II), but the estimated effect was not significant after adjusting for tumour differentiation grade and functional status (Model III).

The last part of Table 2 shows the corresponding results for patient group II. During follow-up, only 19 patients died of prostate cancer. When the analysis was adjusted for age (Model II), tumour differentiation grade and functional status (Model III) a non-significant lower risk of death from prostate cancer was observed for patients with high $25(\mathrm{OH}) \mathrm{D}$ values.

All 37 patients in group I and 60 of the patients in group II had received hormone therapy. These 97 patients, of whom 45 died of prostate cancer, were pooled in a separate analysis (Table 3 ). The mean level of 25(OH)D at blood sampling was 70.7 (s.d. $=25.7$ ) in this group compared with $76.0($ s.d. $=28.1) \mathrm{nmoll}^{-1}$ in the group not receiving any hormones. When age at diagnosis, functional status and tumour differentiation grade were included in the analysis, the relative risk of dying from prostate cancer was 0.18 (95\% CI: $0.07-0.46)$ for patients with medium levels of 25(OH)D compared with patients with low levels. For patients with high serum $25(\mathrm{OH}) \mathrm{D}$, the corresponding result was 0.09 (95\% CI: $0.03-0.27$ ).

\section{Overall mortality}

Sixty-one patients died during follow-up, the majority from prostate cancer. The association between the $25(\mathrm{OH}) \mathrm{D}$ level and death from all causes is similar as for cause-specific mortality and is presented in Table $4(n=160)$. 


\section{DISCUSSION}

Ecological studies provide some evidence of a relationship between insufficient $25(\mathrm{OH}) \mathrm{D}$ levels and cause-specific mortality in patients with prostate cancer (Robsahm et al, 2004; Lim et al, 2006), and if substantiated, this may be of importance for the treatment of prostate cancer patients. The present association study shows a rather strong relationship between serum levels of 25(OH)D and cause-specific mortality, especially in the group of patients who received any type of hormonal treatment.

The strength of this association study is that the observations are on an individual level and in a relatively young study population. The median age is 64.5 years, which is about 10 years younger than the median age at diagnosis for prostate cancer in Norway. The young age occurs due to the JANUS blood collection criteria, which allows only patients who previously have donated serum to the JANUS serum bank, to be included. The patients relatively of young age might be an advantage, as they may be less likely to be hospitalised due to health problems related to old age. Furthermore, there is no reason to believe that the inclusion criteria into the cohort or other methodological issues are influenced by the patients' $25(\mathrm{OH}) \mathrm{D}$ level.

A weakness of the study is that some of the patients (group I) have received hormonal treatment prior to the serum sampling. Although it is possible that the treatment itself could affect the patients' 25(OH)D level, no studies, to our knowledge, have shown that androgen deprivation therapy can influence the $25(\mathrm{OH}) \mathrm{D}$ level (Greenspan, 2008).

Prostate-specific antigen (PSA) is established as a diagnostic and prognostic factor within prostate cancer. In this study, information about individual serum levels of PSA was obtained from the patient medical records. All the patients had high PSA-levels (median $17.7 \mu \mathrm{gl}^{-1}$ ). The inclusion of PSA in the analyses did not affect the estimated hazard ratios when differentiation grade was included in the analyses (not illustrated). Woo et al (2005) observed in a pilot study that a high level of $1,25(\mathrm{OH})_{2} \mathrm{D}$ prolongs the doubling time of PSA, which is in line with our results. Unfortunately, in this study we have no repeated measurements of PSA, and hence we were not able to investigate the possible relationship between $25(\mathrm{OH}) \mathrm{D}$ levels and the doubling time of PSA.

For each patient the $25(\mathrm{OH}) \mathrm{D}$ was measured only once; at the time of hospitalisation. The predictive value of these measurements will depend on the stability of the $25(\mathrm{OH}) \mathrm{D}$ by time. In a reliability study of biomarkers Al-Delaimy et al (2006) show that the Spearman's rank correlation coefficients were 0.68 and 0.58 for 25(OH)D measurements taken at 5-year intervals for men and women, respectively. The authors conclude that no substantial changes in the mean levels occur over time. Also the time between blood sampling and measurement could create noise in the analyses. Lissner et al (1981) have demonstrated a high stability of frozen human blood serum, under several different conditions. Further, Tuohimaa et al (2004) claim that storage time does not influence the vitamin D values in their study. Most of their samples were from JANUS serum bank and hence treated in the same manner as the samples in this study.

The disease may, directly or indirectly, have an impact on the $25(\mathrm{OH}) \mathrm{D}$ level if patients with advanced disease were less able to attend outdoor activities or have unsatisfactory dietary habits with respect to $25(\mathrm{OH}) \mathrm{D}$. This could be the situation in patient group I, where almost all the patients had metastatic disease at the time of blood sampling, and where 33 patients died of prostate cancer during follow-up. However, in this group the median 25(OH)D level was $62.0 \mathrm{nmoll}^{-1}$, which is a rather high level and not very different from the level in the patients with a non-advanced disease at the time of blood sampling $\left(n=114\right.$; median level $\left.73.0 \mathrm{nmoll}^{-1}\right)$. Thus, the disease does not seem to have a strong impact on the patient's 25(OH)D level.
In accordance with our hypothesis, the observed association between $25(\mathrm{OH}) \mathrm{D}$ levels and the mortality rate can express a beneficial effect of holding 25(OH)D levels above a threshold level $\left(50 \mathrm{nmoll}^{-1}\right)$. No dose-response relationship was seen. The differences between the estimates for medium and high serum $25(\mathrm{OH}) \mathrm{D}$ were not significant. Although the major part of the patients included had adequate levels of $25(\mathrm{OH}) \mathrm{D}$, according to recommendations for bone health, we do not know whether there is an optimal level with respect to the prostate health. In this small study including 160 patients in different stages of the disease at blood sampling, the ranges for the $25(\mathrm{OH}) \mathrm{D}$ levels were set to ensure reasonable group sizes without knowledge about the patient's serum level.

There is no general consensus on the optimal level of vitamin D for maintaining health (Wolpowitz and Gilchrest, 2006). Some reviews and meta-analyses indicate that there are different thresholds for various health outcomes (Bischoff-Ferrari et al, 2006; Vieth, 2006; Gorham et al, 2007; Holick, 2007). In this connection results from two incidence studies should be mentioned: Tuohimaa et al (2004) demonstrated a J-shaped dose-effect relationship between vitamin $\mathrm{D}$ and prostate cancer incidence. A recent study by Ahn et al (2008) shows that a high circulating $25(\mathrm{OH}) \mathrm{D}$ level may be associated with an increased risk

Table I Patient clinical characteristics at hospitalisation at the NRH for all patients and patient group I and II separately

\begin{tabular}{|c|c|c|c|c|}
\hline Characteristics & No. & Median & Range & Frequency (\%) \\
\hline $\begin{array}{l}\text { Group } 1+\| \mid \\
\text { Age at diagnosis }\end{array}$ & $\begin{array}{l}160 \\
160\end{array}$ & 64.5 & $52-82$ & \\
\hline $\begin{array}{l}\text { Differentiation grade } \\
\text { High } \\
\text { Moderate } \\
\text { Low }\end{array}$ & $\begin{array}{r}160 \\
35 \\
97 \\
28\end{array}$ & & & $\begin{array}{l}17.5 \\
60.6 \\
21.9\end{array}$ \\
\hline $\begin{array}{l}\text { Calcidiol nmol I-1 } \\
\text { Low }(<50) \\
\text { Medium }(50-80) \\
\text { High }(>80)\end{array}$ & $\begin{array}{r}160 \\
29 \\
82 \\
49\end{array}$ & 72.0 & $19-162$ & $\begin{array}{l}18.1 \\
51.3 \\
30.6\end{array}$ \\
\hline $\begin{array}{l}\text { Functional status } \\
\text { Good } \\
\text { Less good }\end{array}$ & $\begin{array}{r}158 \\
145 \\
13\end{array}$ & & & $\begin{array}{r}91.8 \\
8.2\end{array}$ \\
\hline $\begin{array}{l}\text { Group I } \\
\text { Age at diagnosis }\end{array}$ & $\begin{array}{l}37 \\
37\end{array}$ & 66.7 & $52-79$ & \\
\hline $\begin{array}{l}\text { Differentiation grade } \\
\text { High } \\
\text { Moderate } \\
\text { Low }\end{array}$ & $\begin{array}{r}37 \\
2 \\
18 \\
17\end{array}$ & & & $\begin{array}{r}5.4 \\
48.7 \\
45.9\end{array}$ \\
\hline Calcidiol nmol I-1 & 37 & 62.0 & $25-135$ & \\
\hline $\begin{array}{l}\text { Functional status } \\
\text { Good } \\
\text { Less good }\end{array}$ & $\begin{array}{l}37 \\
26 \\
11\end{array}$ & & & $\begin{array}{l}70.3 \\
29.7\end{array}$ \\
\hline $\begin{array}{l}\text { Group II } \\
\text { Age at diagnosis }\end{array}$ & $\begin{array}{l}123 \\
123\end{array}$ & 65.7 & $54-82$ & \\
\hline $\begin{array}{l}\text { Differentiation grade } \\
\text { High } \\
\text { Moderate } \\
\text { Low }\end{array}$ & $\begin{array}{r}123 \\
33 \\
79 \\
11\end{array}$ & & & $\begin{array}{r}26.8 \\
64.2 \\
9.0\end{array}$ \\
\hline Calcidiol nmol I-1 & 123 & 72.0 & $19-162$ & \\
\hline $\begin{array}{l}\text { Functional status } \\
\text { Good } \\
\text { Less good }\end{array}$ & $\begin{array}{r}121 \\
119 \\
2\end{array}$ & & & $\begin{array}{r}98.3 \\
1.7\end{array}$ \\
\hline
\end{tabular}

aifferentiation grade of tumour tissue; WHO three-grade system 
Table 2 The estimated relationship between serum calcidiol and death from prostate cancer for all patients and patient group I and II separately

\begin{tabular}{|c|c|c|c|}
\hline Variables & $\begin{array}{l}\text { Model I RR } \\
\text { (95\%Cl) }\end{array}$ & $\begin{array}{c}\text { Model II RR } \\
(95 \% \mathrm{CI})\end{array}$ & $\begin{array}{c}\text { Model III RR } \\
(95 \% \mathrm{Cl})\end{array}$ \\
\hline $\begin{array}{l}\text { roup I+II }(n=\mid 60) \\
\text { Calcidiol }\left(\left.\mathrm{nmol}\right|^{-1}\right) \\
\text { Low }(<50) \\
\text { Medium }(50-80) \\
\text { High }(>80)\end{array}$ & $\begin{array}{l}\text { I.00 (ref) } \\
0.48(0.24-0.97) \\
0.34(0.15-0.77)\end{array}$ & $\begin{array}{l}1.00 \text { (ref) } \\
0.41(0.20-0.85) \\
0.22(0.09-0.53)\end{array}$ & $\begin{array}{l}1.00 \text { (ref) } \\
0.33(0.14-0.77) \\
0.16(0.05-0.43)\end{array}$ \\
\hline Group status & & $0.05(0.03-0.10)$ & $0.05(0.03-0.10)$ \\
\hline Age (I year) & & $1.00(0.96-1.03)$ & $1.00(0.95-1.03)$ \\
\hline $\begin{array}{l}\text { Differentiation grade } \\
\text { High } \\
\text { Moderate } \\
\text { Low }\end{array}$ & & & $\begin{array}{l}1.00(\mathrm{ref}) \\
1.56(0.42-5.06) \\
7.01(1.91-25.7)\end{array}$ \\
\hline $\begin{array}{l}\text { Functional status } \\
\text { Good } \\
\text { Less good }\end{array}$ & & & $\begin{array}{l}1.00(\mathrm{ref}) \\
1.22(1.00-1.50)\end{array}$ \\
\hline $\begin{array}{l}\text { Group I }(n=37) \\
\text { Calcidiol }\left(n m o I^{-1}\right) \\
\text { Low }(<50) \\
\text { Medium }(50-80) \\
\text { High }(>80)\end{array}$ & $\begin{array}{l}1.00 \text { (ref) } \\
0.31(0.13-0.73) \\
0.26(0.10-0.68)\end{array}$ & $\begin{array}{l}1.00 \text { (ref) } \\
0.30(0.12-0.73) \\
0.25(0.09-0.69)\end{array}$ & $\begin{array}{l}1.00(\mathrm{ref}) \\
0.51(0.14-1.78) \\
0.41(0.11-1.54)\end{array}$ \\
\hline Age (I year) & & $0.99(0.95-1.04)$ & $0.99(0.94-1.04)$ \\
\hline $\begin{array}{l}\text { Functional status } \\
\text { Good } \\
\text { Less good }\end{array}$ & & & $\begin{array}{l}1.00(\mathrm{ref}) \\
2.03(0.61-6.68)\end{array}$ \\
\hline $\begin{array}{l}\text { Group II }(n=123) \\
\text { Calcidiol }\left(n m o l I^{-1}\right) \\
\text { Low }(<50) \text { Medium } \\
(50-80) \\
\text { High }(>80)\end{array}$ & $\begin{array}{l}1.00 \text { (ref) } \\
0.73(0.24-2.24) \\
0.57(0.17-1.91)\end{array}$ & $\begin{array}{l}1.00 \text { (ref) } \\
1.14(0.24-5.36) \\
0.62(0.11-3.57)\end{array}$ & $\begin{array}{l}1.00(\mathrm{ref}) \\
1.05(0.21-5.13) \\
0.59(0.10-3.47)\end{array}$ \\
\hline Age (I year) & & $0.92(0.85-1.00)$ & $0.93(0.86-1.00)$ \\
\hline $\begin{array}{l}\text { Functional status } \\
\text { Good } \\
\text { Less good }\end{array}$ & & & $\begin{array}{l}1.00(\mathrm{ref}) \\
1.17(0.88-1.54)\end{array}$ \\
\hline $\begin{array}{l}\text { Differentiation grade } \\
\text { High } \\
\text { Moderate } \\
\text { Low }\end{array}$ & & & $\begin{array}{l}1.00 \text { (ref) } \\
1.60(0.35-7.34) \\
4.91(0.81-29.8)\end{array}$ \\
\hline
\end{tabular}

${ }^{a}$ Differentiation grade of tumour tissue; WHO three-grade system.

of aggressive disease. Both studies indicate that high serum levels of $25(\mathrm{OH}) \mathrm{D}$ can be problematic and thus, the general communication of the result in this study should be done with caution.

The plausibility of an effect of 25(OH)D exists. 25(OH)D can act as a substrate for the $1, \alpha$-hydroxylation and production of $1,25(\mathrm{OH})_{2} \mathrm{D}$ in the prostate or $25(\mathrm{OH}) \mathrm{D}$ might bind itself to the VDR in the prostate cells and act by itself (Schwartz, 2005). Several experimental studies have demonstrated the anti-invasive and anti-metastatic effect of vitamin D on prostate cells, through its promotion of differentiation and apoptosis and its inhibiting effect on angiogenesis and proliferation (see Dunlap et al, 2003). Our results are consistent with the ecological studies showing the lowest death risk among patients diagnosed in seasons with high ultraviolet radiation exposure (Robsahm et al, 2004; Lim et al, 2006). These results from ecological studies are not in accordance with an influence of the prostate cancer disease on the level of vitamin $\mathrm{D}$. The results in the present study are also consistent with an inverse relationship between plasma 25(OH)D levels and
Table 3 The estimated relationship between serum calcidiol and death from prostate cancer among patients receiving hormone therapy $(n=97)$

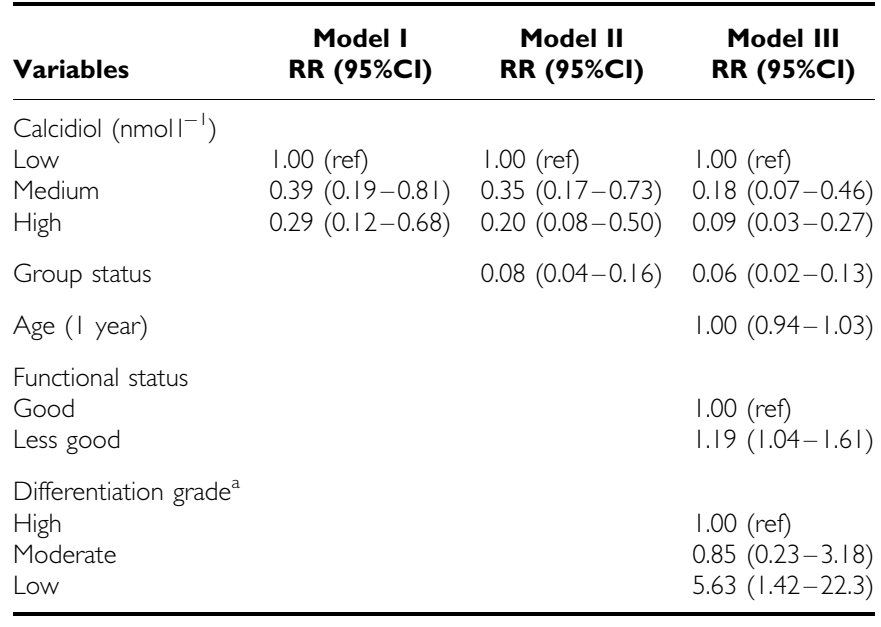

${ }^{\mathrm{a} D i f f e r e n t i a t i o n ~ g r a d e ~ o f ~ t u m o u r ~ t i s s u e ; ~ W H O ~ t h r e e-g r a d e ~ s y s t e m . ~}$

Table 4 The estimated relationship between serum calcidiol and death from all causes $(n=160)$

\begin{tabular}{|c|c|c|c|}
\hline Variables & $\begin{array}{c}\text { Model I } \\
\text { RR (95\%Cl) }\end{array}$ & $\begin{array}{c}\text { Model II } \\
\text { RR }(95 \% \mathrm{Cl})\end{array}$ & $\begin{array}{c}\text { Model III } \\
\text { RR }(95 \% \mathrm{Cl})\end{array}$ \\
\hline $\begin{array}{l}\text { Calcidiol }\left(\mathrm{nmol} \mathrm{I}^{-1}\right) \\
\text { Low } \\
\text { Medium } \\
\text { High }\end{array}$ & $\begin{array}{l}1.00 \text { (ref) } \\
0.41(0.21-0.79) \\
0.35(0.17-0.2)\end{array}$ & $\begin{array}{l}1.00 \text { (ref) } \\
0.37(0.19-0.73) \\
0.23(0.11-0.51)\end{array}$ & $\begin{array}{l}1.00 \text { (ref) } \\
0.40(0.20-0.78) \\
0.24(0.11-0.53)\end{array}$ \\
\hline Group status & & $0.08(0.05-0.14)$ & $0.08(0.05-0.14)$ \\
\hline Age (I year) & & & $1.00(0.97-1.04)$ \\
\hline $\begin{array}{l}\text { Functional status } \\
\text { Good } \\
\text { Less good }\end{array}$ & & & $\begin{array}{l}1.00(\mathrm{ref}) \\
1.32(1.08-1.6 \mathrm{I})\end{array}$ \\
\hline
\end{tabular}

mortality that have been reported for early-stage lung cancer and for colorectal cancer (Zhou et al, 2007; Ng et al, 2008).

It has been hypothesised that vitamin D can amplify the effect of cancer treatment; a synergistic effect that has been observed in both experimental and clinical studies (Dunlap et al, 2003; Deeb et al, 2007). Furthermore, results from experimental studies also indicate an interaction between sexual hormones and vitamin D metabolism (Nyomba et al, 1987; Sarem and Pedersen, 1988; Bolland et al, 2007). The androgen testosterone is synthesised from cholesterol and has a similar structure as vitamin D, and acts through nuclear receptors that belong to the same chemical family as VDR. Thus, a possible explanation for the observed association between $25(\mathrm{OH}) \mathrm{D}$ levels and mortality in group I (Table 2) and for the patients on hormone therapy in groups I and II combined (Table 3) might be that $25(\mathrm{OH}) \mathrm{D}$ amplifies the therapeutic effects of lowering androgen levels and/or activity and hence improve the cancer prognosis. Among the patients treated without hormones only seven patients died of prostate cancer. This makes it impossible to make an appropriate survival analysis for other treatments than hormone therapy. The different results between group I and II (Table 2, model III), might be due to a difference in the stage of disease. In group II only 19 deaths occurred during follow-up, which indicate the need for longer follow-up or new larger studies.

To conclude, this study shows a strong association between 25(OH)D levels and cause-specific mortality in patients with 
prostate cancer. The strength of the association indicates that prostate cancer patients can benefit from increasing the level of serum $25(\mathrm{OH}) \mathrm{D}$ if it is below $50 \mathrm{nmoll}^{-1}$. However, association studies do not set out to prove causality and several uncertainties exist in the present study. A randomised trial should be carried out, giving the patients vitamin $\mathrm{D}$ in addition to the standard cancer treatment.

\section{REFERENCES}

Ahn J, Peters U, Albanes D, Purdue MP, Abnet CC, Chatterjee N, Horst RL, Hollis BW, Huang W-Y, Shikany JM, Hayes RB (2008) Serum vitamin D concentration and prostate cancer risk: A nested case-control study. J Natl Cancer Inst 100: 796-804

Al-Delaimy WK, jansen EHJM, Peeters PHM, Van Der Laan JD, Van Noord PAH, Boshuizen HC, Van Der Schouw YT, Jenab M, Ferarri P, Bueno-deMesquita HB (2006) Reliability of biomarkers of iron status, blood lipide, oxidative stress, vitamin $\mathrm{D}, \mathrm{C}$-reactive protein and fructosamine in two Dutch cohorts. Biomarkers 11: $370-382$

Apperly FL (1941) The relation of solar radiation to cancer mortality in North America. Cancer Res 1: $191-195$

Berwick M, Armstrong BK, Ben-Porat L, Kricker A, Eberle C, Barnhill R (2005) Sun exposure and mortality from melanoma. J Natl Cancer Inst 97: $195-199$

Bischoff-Ferrari HA, Giovannucci E, Willett WC, Dietrich T, Watson-Hughes B (2006) Estimation of optimal serum concentration of 25-hydroxyvitamin D for multiple health outcomes. Am J Clin 84: $18-28$

Bolland MJ, Grey AB, Ames RW, Horne AM, Mason BH, Wattie DJ, Gamble GD, Bouillon R, Reid IR (2007) Age-, gender- and weight-related effects on levels of 25-hydroxyvitamin $\mathrm{D}$ are not mediated by vitamin $\mathrm{D}$ binding protein. Clin Endocrinol 67: 259-264

Deeb KK, Trump DL, Johnson CS (2007) Vitamin D signalling pathways in cancer: Potential for anticancer therapeutics. Nat Rev Cancer 7: 684-700, doi: $10.1038 /$ nrc.2196

Dunlap N, Schwartz GG, Eads D, Cramer SD, Sherk AB, John V, Koumenis C (2003) 1 $\alpha, 25$-Dihydroxyvitamin $\mathrm{D}_{3}$ (calcitriol) and its analogue, 19-nor- $1 \alpha, 25(\mathrm{OH})_{2} \mathrm{D}_{2}$, potentiate the effect of ionising radiation on humane prostate cancer cells. Brit J Cancer 89: 746-753

Freedman DM, Dosemeci M, McGlynn K (2002) Sunlight and mortality from breast, ovarian, colon, prostate, and non-melanoma skin cancer: a composite death certificate based case-control study. Occup Environ Med 59: 257 -262, doi:10.1093/jnci/djm.204

Freedman DM, Looker AC, Chang SC, Graubard BI (2007) Prospective study of serum vitamin D and cancer mortality in the United States. J Natl Cancer Inst 99: 1594-1602

Garland CF, Garland FC (1980) Do sunlight and vitamin D reduce the likelihood of colon cancer? Int J Epidemiol 9: 227-231

Giovannucci E (2005) The epidemiology of vitamin D and cancer incidence and mortality: a review (US). Cancer Causes Control 16: 83-95

Gorham ED, Garland CF, Garland FC, Grant WB, Mohr SB, Lipkin M, Newmark HL, Giovannucci E, Wei M, Holick MF (2007) Optimal vitamin D status for colorectal prevention, a quantitative meta analysis. Am J Prev Med 32: $210-216$

Grant WB (2002) An estimate of premature cancer mortality in the US due to inadequate doses of solar ultra-violet-B radiation. Cancer 94: $1867-1875$

Greenspan SL (2008) Approach to the prostate cancer patient with bone disease. J Clin Endocrinol Metab 93: 2-7

Hansen CM, Binderup L, Hamberg KJ, Carlberg C (2001) Vitamin D and cancer: effects of $1,25(\mathrm{OH})_{2} \mathrm{D}_{3}$ and its analogs on growth control and tumor genesis. Front Bioski 6: D820-D848

Holick MF (2006) Vitamin D; its role in cancer prevention and treatment. Prog Biophys Mol Biol 92: 49-559

Holick MF (2007) Vitamin D deficiency. $N$ Engl J Med 19: 357: 266-281

John EM, Schwartz GG, Dreon DM, Koo J (1999) Vitamin D and breast cancer risk: The NHANES I Epidemiological follow-up study, 1971-1975 to 1992. Cancer Epidemiol Biomark Prev 8: 399-406

Johnsen B, Mikkelborg O, Hannevik M, Nilsen LT, Saxebøl G, Blaasaas KG (2002) The Norwegian UV monitoring program period 1995/96 to 2001. Radiation Protection Authority: Østerås, Norway, pp 23-24

\section{ACKNOWLEDGEMENTS}

The study was recommended by the National Committee for Research Ethics and approved by the Norwegian Data Inspectorate, the Directorate for Health and Social Affairs, the JANUS committee and the Protocol Committee at the Norwegian Radium Hospital.
Lim HS, Roychoudhuri R, Peto J, Schwartz G, Baade P, Møller H (2006) Cancer survival is dependent on season of diagnosis and sunlight exposure. Int J Cancer 119: 1530 - 1536

Lissner D, Mason RS, Posen S (1981) Stability of vitamin D metabolites in human blood serum and plasma. Clin Chem 27: $773-774$

Luscombe CL, Fryer AA, French ME (2001) Exposure to ultraviolet radiation: association with susceptibility and age at presentation with prostate cancer. Lancet 358: $641-642$

Moan J, Porojnicu AC (2006) The photobiology of vitamin D-a topic of renewed focus. Tidskr Nor Logefor 126: 1048 -1052, (in Norwegian)

Mostofi FK (1980) Histological typing of prostate tumors. International classification of tumors No. 22, World Health Organization: Geneva

Ng K, Meyerhardt JA, Wu K, Feskanich D, Hollis BW, Giovannucci EL, Fuchs CS (2008) Circulating 25-Hydroxvitamin D levels and survival in patients with colorectal cancer. J Clin Oncol 36: 2984-2991

Nyomba BL, Bouillon R, De MP (1987) Evidence for an interaction of insulin and sex steroids in the regulation of vitamin $\mathrm{D}$ metabolism in the rat. J Endocrinol 115: 295 - 301

Oken MM, Creech RH, Tormey DC, Horton J, Davis TE, McFadden ET, Carbone PP (1982) Toxicity and response criteria of the eastern cooperative oncology group. Am J Clin Oncol 5: 649-655

Omdahl JL, Morris HA, May BK (2002) Hydroxylase enzymes of the vitamin D pathway: expression, function, and regulation. Annu Rev Nutr 22: 139 - 166

Porojnicu AC, Robsahm TE, Ree AH, Moan J (2005) Season of prognosis is a prognostic factor in Hodgkin's lymphoma: a possible role of suninduced vitamin D. Br J Cancer 93: $571-574$

Porojnicu AC, Robsahm TE, Dahlback A, Berg JP, Christiani D, Bruland OS, Moan J (2007) Seasonal and geographical variations in lung cancer prognosis in Norway. Does vitamin D from the sun play any role? Lung Cancer 55: 263 -270, doi: 10.1016/j.lungcan.2006.11.013

Robsahm TE, Tretli S, Dahlback A, Moan J (2004) Vitamin D from sunlight may improve the prognosis of breast-, colon- and prostate cancer (Norway). Cancer Causes Control 2: 149-158

Sarem K, Pedersen JI (1988) Sex differences in the hydroxylation of cholecalciferol and of 5 beta-cholestane- 3 alpha, 7 alpha, 12 alpha-triol in rat liver. Biochem J 247: $73-78$

Schwartz GG, Hulka BS (1990) Is vitamin D deficiency a risk factor for prostate cancer? Hypothesis). Anticancer Res 10: 1307-1311

Schwartz GG, Whitlatch LW, Chen TC, Lokeshwar BL, Holick MF (1998) Human prostate cells synthesize 1,25- hydroxyvitamin $\mathrm{D}_{3}$ from 25hydroxyvitamin $\mathrm{D}_{3}$. Cancer Epidemiol Biomark Prev 7: $391-395$

Schwartz GG (2005) Vitamin D and the Epidemiology of Prostate Cancer. Seminars in Dialysis 18: 276-289

SPSS for Windows, version 15.0, Chicago, Illnois, Spss Inc, 2007

Tuohimaa P, Tenkanen L, Ahonen M, Lumme S, Jellum E, Hallmans G, Stattin P, Harvei S, Hakulinen T, Luostarinen T, Dillner J, Lethinen M, Hakama M (2004) Both high and low levels of blood vitamin D are associated with a higher prostate cancer risk: a longitudinal, nested casecontrol study in the nordic countries. Int J Cancer 108: 104-108

Vieth R (2006) What is the optimal vitamin D status for health. Prog Biophys Mol Biol 92: 26-32, doi: 10.1016/j.pbiomolbio.2006.02.003

Wolpowitz D, Gilchrest BA (2006) The vitamin D questions: how much do you need and how should you get it? J Am Acad Dermatol 54: $301-317$

Woo TCS, Choo R, Jamieson M, Chander S, Vieth R (2005) Pilot study: potential role of vitamin $\mathrm{D}$ (cholecalciferol) in patients with PSA relapse after definitive therapy. Nutr Cancer 51: 32-36

Zhou W, Heist RS, Liu G, Asomaning K, Neuberg DS, Hollis BW, Wain JC, Lynch TJ, Giovannucci E, Su L, Christiani DC (2007) Circulating 25hydroxyvitamin D levels predict survival in early-stage non-small lung cancer patients. J Clin Oncol 25: 479-485 